\title{
The Traditional Game Learning Model for the Elementary School Student Character Building
}

\author{
Septian Fajri Masyhuri*, Wawan S Suherman \\ Program Pascasarjana Ilmu Keolahragaan \\ Yogyakarta State University \\ Daerah Istimewa Yogyakarta, Indonesia \\ *septianfajri30@gmail.com, wansuherman@uny.ac.id
}

\begin{abstract}
The purpose of the research was to produce a learning method based on traditional games which suits to primary school student characteristics, easy and safe for primary school students to play with, and also an effective development method to develop honesty, disciplinary, and responsibility. The research method used was research and development method or RnD. This method is used to produce a product in a form of a learning method based on traditional games to build the character of primary school students. The research steps were: (1) preliminary study, information collection and literature analysis needs, observation, and research scheme work composition (2) planning (objectives formulation, the determination of learning sequence) (3) the development of initial product (learning material preparation, evaluation of instrument) (4) initial field trial (small scope trial) (5) revision of the main product (based on the suggestion post the initial trial) (6) primary field trial (big scope trial) (7) product revision (based on the result of big scope trial) (8) affectivity trial (9) final product revision (10) dissemination and implementation. The data analysis techniques used were descriptive quantitative analysis and descriptive qualitative analysis. The result of this research is a manual boof of learning method based on traditional games to develop honesty, discipline, and responsibility characters.
\end{abstract} games

Keywords: character building, learning model, traditional

\section{INTRODUCTION}

Character building in this millennium era placed attracts special attention from the Indonesian government. There are various attempts has been done to develop the nation character. One of the attempt was to create some activities to shape, develop and to make a habit of Indonesian people with some activities which can be support the quality improvement of Indonesian people character. In line with the issuance of Perpres No. 87 Year 2017 regarding the Strengthening of Character Building is a prove of the severance of the government with regards to the character building matter. The government of Indonesia believe that preparing young generation is the only way to go to be a very strong nation in 2045 [1].

The study of the character building of early age has become one of the government program, to prepare a good generation with good character from the very beginning. , Character is central to positive psychology's efforts to understand and promote human flourishing [2]. The teachers nowadays, face the problem of the changing of the era, different character of the current children character compare to a couple of years back then, moreover the vast technology development, all the information accessible through one gadget. This become challenging to teachers to deal with millennium generation. The demand to shape the to be skilful and creative, becomes one teacher's skill should have, to face the vast era development which eventually will give impact to the students' psychologic mindset.

The issue regarding the importance of the character building has been spread as soon as after the media exposing the moral and ethics degradation of young age. Moral crisis in the society can be seen by (1) the loss of honesty (2) the loss of responsibility (3) lack of visioner ability (4) lack of discipline (5) cooperation crisis (6) justice crisis and (7) empathy crisis. The tendency of violent behaviour can be considered as on of the moral crisis symptom. The moral crisis symptoms arises among the students, suspected as the effect of globalization, strengthened by development and sophisticated communication and information technology growth. The growth of technology in the globalization era is vast, which opens big opportunity for western culture to influence the children's nation behaviour. If we look deeper to our culture, the western culture is not in line with the local culture. From the technology and information development such as television, social media, and internet, becomes the most effective media to relay information. There are many programs contains violence, becomes the children's main show to watch. Not only violence, adult romance also frequently shown, which was inappropriate to be seen by children. The more the children see those programmes the more it affects their character development and build them to become less good person. Many of the negative impacts that will arise include: will be difficult to socialize, slow in motor development, and significant behavioural changes. So it is very important role of parent to supervise, control and pay attention to all activities of children [3].

The character building is needed to overcome the Indonesian culture value dissolvement, which suspectedly will result in the weakness of the nation's character. Character is a different term which more or less will have the same meaning as personality. Teaching character must be as important as academic teaching, the community will continue to be in a state of chaos until the character is taught at school again. In this 
classmate. LIPUTAN6.COM in Sukabumi, 2 best friends were raped by their classmates. In Karawang, SINDONEWS.COM primary school student in Yogyakarta were caught drinking alcohol. And not to mention the bullying cases, romance among primary school's students was very apprehensive. There are many factors that caused this reality such as economics condition, the parents's low education level, parents' divorce [7]. The study concludes that in terms of the influencing factors of character education integrated into parent-child relationship [8] by looking at the background, the researches try to do some observation and interviews to some teachers in Yogyakarta. How was the character of most students nowadays and which methods implemented by the teachers to build the student's character at their early age. The observation and interview result, the researcher gain a general description such as the implementation of physical education is not yet been optimalized, to be use as character building. The fact attracts the researcher to develop a learning method based on traditional games to build honesty, discipline and responsibility character to the primary school students.

\section{METHOD}

The research method is research and development which commonly known as (research and development or R n D). This method is being use by the researcher to produce a learning method based on the traditional games to build character of primary school's student.

\section{A. The Development Procedure}

The research and development procedure with steps as follows : demands analysis, product design, design validation, design revision, small scope trial, product revision, product revision, big scope trial, product revision, effectiveness trial, final product and dissemination [9].

\section{B. Design Trial}

The purpose of the design trial is to collect data which can be use as the foundation of the effectiveness, efficiency or the attraction of the product. The trial also performed to complement the learning method based on the traditional games by hands-on learning.

The field trial executed three times which are small scope field trial, big scope field trial and effectiveness trial. The small scope trial or limited trial used to give description about the planned product. The big scope trial executed to gain information of the feasibility of the learning method based on the traditional games. The effectiveness trial executed to gain information of the effectiveness by requiring some advise from the experts whom are children physical education material expert, the traditional games experts, towards the implementation of the learning method based on the traditional games.

\section{Data Type}

The data type is obtained from this research is qualitative data and quantitative data. Qualitative data is based on (1) input/advise from the experts to complement the product, and (2) interview result of teachers from Primary schools. KOMPAS.COM a Grade 2 student died after fighting with his 


\section{RESULTS AND DISCUSSION}

Qualitative date is obtained from (1) result from score scale from contact expert (2) data from model observation score from content material expert (3) data from observation evaluation and model effectiveness from the expert. Those data are used to evaluate learning method based on traditional games to develop character of primary school's student.

\section{Subject}

This research is applied to students from three different school, which are (1) small scope trial executed in 1 elementary school which involved 30 Grade 3 students. (2) big scope trial executed in 2 elementary schools which involved 60 Grade 3 students.

\section{E. Data Collection Technique}

The data collection technique is a way that use to collect data. The qualitative data technique is obtained during literature study, field observation, interview, field record, and documentation study. Whereas, the quantitative data obtained by using questioner, evaluation forms which are used by the expert to evaluate the developed model to give advices and critics. After some trials both big and small scope. Besides, the evaluation form is also use to evaluate the experiment in the effectiveness trial with different subject from big scope trial and small scope trial.

\section{F. Data Collection Instrument}

The instrument used to assess whether the product has been developed well from different aspects such as content, display and useful. Instrument used produced 2 types of data, which are qualitative data and quantitative data. Qualitative data obtained from interview of some primary school teachers, whereas quantitative data obtained from the evaluation from the experts toward the development of the learning method based on the traditional games to develop character. Those data are useful to assess the feasibility of the development itself.

\section{G. Data Analysis Technique}

Data analysis technique in the research and development use qualitative and quantitative analysis. The technique of the qualitative data analysis in this research is executed together with data collection. The data analysis process is performed by reducing data which is finishing process, simplification, transformation, abstraction and data focusing. The data reduction is performed continuously from the beginning to the end of data collection. After data reduction, the next data analysis activity is data presentation and data conclusion. The qualitative data at the preliminary study in the form of observation result, interview and written documentation reduction data, presented for description. The last step will be conclusion to describe the existing problem in detail. Those must be done to strengthen the background of the research. In the process of product development, the data in the form of revision advise is being reduced, presented, then to be analysed to obtain conclusion as the revision material.
The result of this research is a learning method based on the traditional games to build honesty, discipline and responsibility character which arranged in the form of manual book, learning method, which contain (1) concept (2) basic competencies (3) purpose of learning (4) content (5) syntax (6) teachers and students activity (7) evaluation of learning result.

\section{A. Concepts}

The learning method based on the traditional games to develop honesty discipline and responsibility character makes traditional games as a tool in every learning process. The traditional games has been classified and adjusted according to the competence of the Physical education of lower grades. In that case, the characteristic of the traditional games used must become a tool to develop the cognitive domain, affective and psychomotoric, to achieve competency from Physical education subject. In that, traditional games becomes a learning tool that is costumisedly arranged to build a learning method. What makes the learning method based on the traditional games compare to the other learning method is the character implementation in each of the games they played, one of them is traditional Javanese games, Javanese culture is an ancient culture steeped in the philosophy is suitable to applied in the formation of character IESQ in Children[10]. In the past learning method, usually only focus on the cognitive domain and psychomotoric, whereas in the learning method based on the traditional games, the development will lead to affective, cognitive and psychomotoric aspects. In the traditional games there are character values which can develop honesty, discipline and responsibility, basic movement of locomotors, non-locomotors, manipulative as well as the comprehension of the games such as rules, strategy and knowledge about the physical activity. To integrate the cognitive development and psychomotoric and the character development which include in the affective domain. So that the development of honesty, discipline and responsibility character goes along with the development of the concerned's student motoric and cognitive. There for the choice of traditional games as well as the model arrangement must be made according to the competency of the lower grade with a purpose PE learning can be achieved.

As there is the learning method based on the traditional games, it is hopeful it can be a referral for teachers to choose a learning method that can be able to integrate with 3 domain which are cognitive, affective and psychomotoric. Wherease for students, it is hopeful the development of their cognitive, affective and psychomotoric can go together, especially the ability to develop honesty, discipline and responsibility character.

\section{B. Basic Competency}

Basic competency is competency in each subject for each class described from Core Competencies. Basic Competency is content or competencies which consist of behaviour, skill and knowledge which based on the core competencies which must be mastered by the students. Those competencies are developed by paying attention on the characteristic of the students, preliminary skills, as well as the character of a subject. Competencies and scope of contact used to determine 
player within the circle should try to avoid the defender without getting out of the circle.
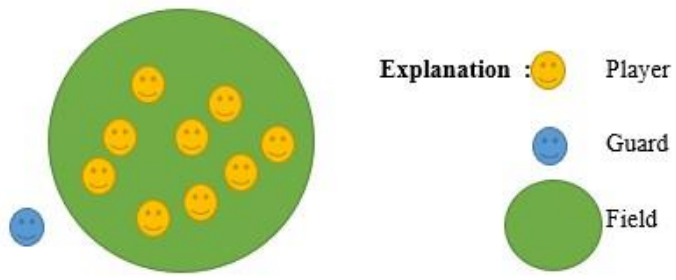

Fig. 2. Demok dadi.

Bentengan (Fortress guarding) is a game without tool, played by two teams, consist of 4 players each. The shape of the field is rectangular and the duration is about 15 minutes. Each group choose which pole or tree as their fortress. The team whom can take over the opponent's fortress will be the winner. It is just taking over the fortress is not as easy as it says, because apart from taking over the fortress they also have to guard at the same time.
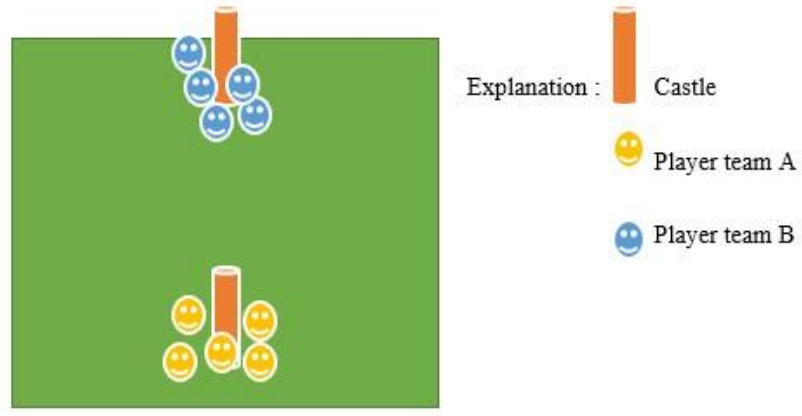
are traditional games which has value of honesty, discipline and responsibility: (1) gobaksodor (2) demok dadi (3) betengan (4) tawon tawonan

Gobak sodor. Gobak sodor is game that is consist of two teams. One team consist of 3 people or more. The purpose of the game is to block the opponent to pass over the last defense line, back and forth within the designated area. One player will be the defender, the defense line will be until the middle of the field. The difficulties is based on the process of crossing the line without getting touch by the opponent, therefore it needs the skill to run, and strategy on body movement so it cannot be touch by the defender.

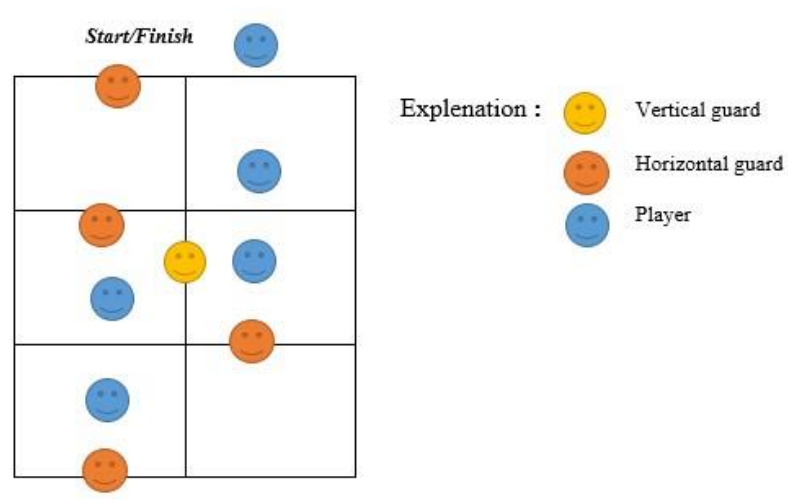

Fig. 1. Gobak sodor

Demok Dadi Games. This game creates one to be a defender whom tries to reach or to touch the player whom are within the circle without getting into the circle. Whereas the
Fig. 3. Bentengan.

Tawon tawonan (bees) is a game consist of 5-10 players with 1 player as the Bee. The Bee will run after the other player to shoot its sting. Once one of the player got stinged, the stinged player becomes the Bee, and so on.

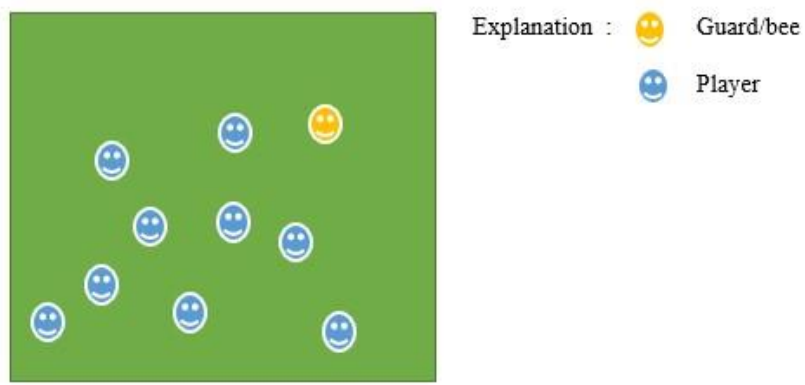

Fig. 4. Tawon tawonan.

\section{E. Syntax/Learning Steps}

In the learning based on the traditional games, the learning steps executed not different from the other methods. However, the difference is the use of the traditional games in every learning session as well as the model effectiveness in developing honesty, discipline and responsibility character. 
outcomes. According to experts the learning model is in accordance with the characteristics of elementary school students, safe, fun and effective to develop the character of honesty, discipline, and responsibility.

\section{REFERENCES}

\section{G. End Result Evaluation}

Evaluation becomes integral part of learning process. To understand and to know how to use the method precisely is very important, in order to provide an effective learning session. Evaluation helps teacher to acknowledge the strength and the weakness of the student as well as to supervise their progress whenever the study is in progress.

The evaluation in the primary school contains four main activities which are series of teachers work, which are (1) observation : the process of observing students when they play on some activities and study (2) recording: process of documentation on several activities which observed well (3) analysis towards information and data that is obtained as the basic of the decision (4) reporting: the process of information presentation to management and parents in the form of progress report, both oral and written.

\section{CONCLUSIONS}

The results of this study are a traditional game-based PJOK learning model to develop an honest character of discipline and responsibility in elementary school students. This model has several components: (1) concepts (2) the purpose of learning (3) content (traditional gobak sodor games, bentengan, tawon tawonan, demok dadi). (4) Syntax / step learning steps (5) teacher and student activities (6) assessment of learning
[1] F. Rokhman, M. Hum, A. Syaifudin and Yuliati, "Character education golden years)," Procedia - Social and Behavioral Sciences, vol. 141, pp. 1161-1165, 2014.

[2] B. J. Fowers, "From continence to virtue," Theory \& Psychology, vol. 18(5), pp. 629-653, 2008.

[3] A.C. Puji, "Pengaruh media gadget pada perkembangan karakter anak," Jurnal Dinamika Penelitian: Media Komunikasi Penelitian Sosial Keagamaan, pp. 315-330, 2018.

[4] T. Gray, "Character education in schools," Journal Essai, vol. 7(21), pp. 56-61, 2009.

[5] G. Aurelian and B. Iuliana, "The education of the self and feminine body aesthetics through physical exercise and effective communication," Procedia - Social and Behavioral Sciences, vol. 131, pp. 198-201, 2014.

[6] M. Ülger, S. Yiğittir and O. Ercan, "Secondary school teachers' beliefs on character education competency," Procedia - Social and Behavioral Sciences, vol. 131, pp. 442-449, 2014.

[7] N. Knaappila, M. Marttunen, S. Fröjd, N. Lindberg and R.K. Heino, "Socioeconomic trends in school bullying among finnish adolescents from 2000 to 2015," Child Abuse \& Neglect, vol. 86, pp. 100-108, 2018.

[8] C. Mei-Ju, Y.C. Hsin and H. Pin-Chen, "The Beauty of Character Education on Preschool Children's Parent-child Relationship," Procedia - Social and Behavioral Sciences, vol. 143, pp. 527-533, 2014.

[9] W.R. Borg and M.D. Gall, "Educational research an introduction," New York: Longman, 2007.

[10] E. Ferdiawan and W.E. Putra, "Esq Education for Children Character Building based on Phylosophy of Javaness in Indonesia," Procedia Social and Behavioral Sciences, vol. 106, pp. 1096-1102, 2013. for golden generation 2045 (national character building for indonesian 